Article

\title{
Changes in Assimilation Area and Chlorophyll Content of Very Early Potato (Solanum tuberosum L.) Cultivars as Influenced by Biostimulants
}

\author{
Wanda Wadas $1, *$ (1) and Tomasz Dziugieł ${ }^{2}$ \\ 1 Institute of Agriculture and Horticulture, Faculty of Agrobioengineering and Animal Husbandry, Siedlce \\ University of Natural Sciences and Humanities, B. Prusa 14, 08-110 Siedlce, Poland \\ 2 Main Inspectorate of Plant Health and Seed Inspection, Voivodeship Plant Health and Seed Inspection \\ Service, Żółkiewskiego 17, 05-075 Warszawa-Wesoła, Poland; tomasz_dziugiel@wp.pl \\ * Correspondence: wanda.wadas@uph.edu.pl
}

Received: 7 February 2020; Accepted: 10 March 2020; Published: 12 March 2020

\begin{abstract}
This paper analyses the effects of foliar application of the seaweed extracts Bio-algeen S90 (Ascophyllum nodosum) and Kelpak SL (Ecklonia maxima), as well as the humic and fulvic acids ini HumiPlant (leonardite extract), on the assimilation area and chlorophyll content of very early potato cultivars ('Denar', 'Lord', Miłek'). The field experiment was carried out in central-eastern Poland over three growing seasons, using Luvisol. The biostimulants were applied according to the manufacturers' recommendations. The use of biostimulants resulted in enlargement of the assimilation area, but had no effect on the specific leaf area (SLA) or chlorophyll content (Soil Plant Analysis Development (SPAD) value). The assimilation area was larger, on average, by $0.0505 \mathrm{~m}^{2}$ and leaf area index (LAI) was higher by 0.30 compared with the plants from the control group without a biostimulant. The SLA and SPAD depend on the cultivar and weather conditions, or nitrogen and magnesium content in soil, to a greater extent. The biostimulants enhanced abiotic stress tolerance and increased marketable tuber yield (diameter above $30 \mathrm{~mm}$ ) 75 days after planting (the end of June), on average by 2.15 t.ha ${ }^{-1}$. Bio-algeen S90 and Keplak SL produced better results in a warm and very wet growing season, whereas HumiPlant produced better results in a year with lower air temperature and with drought periods during potato growth. No correlations were found between the tuber yield and assimilation area or between the tuber yield and SPAD value, although a significant negative correlation was found between the tuber yield and SLA.
\end{abstract}

Keywords: seaweed extract; humic acids; leaf area index (LAI); specific leaf area (SLA); Soil Plant Analysis Development (SPAD) index; tuber yield

\section{Introduction}

In recent years, the growth and productivity of crop plants have been greatly influenced by abiotic stresses. Periods of high temperature and drought are becoming more frequent in regions with extensively crop production, such as Central Europe, South-Central Asia, south-eastern South America and the south-eastern United States [1]. Under climate change conditions, biostimulants play an important role in sustainable crop production. These natural products (seaweed extracts, humic substances, hydrolysed proteins, and amino acids containing products or microorganism) contain a bioactive substance which enhances nutrition efficiency, abiotic stress tolerance, and/or crop quality traits, regardless of its nutrients content [2-5]. In recent years, the use of seaweed extracts and humic substances as plant growth stimulants has been increasing. Seaweed extracts and humic acids can promote plant growth, enhance abiotic stress tolerance as well as increase nutrient use efficiency [6-10]. 
Many plant growth-stimulating compounds (auxins, cytokinins, gibberellins, betaines, polysaccharides, polyamines, abscisic acids, brassinosteroids, and minerals) have been identified from seaweed. The chemical composition of seaweed extracts depends on the algae species and on the method of extraction. Brown algae (Phaeophyta) are most commonly used for the manufacture of extracts used as biostimulants of plant growth, including Ascophyllum nodosum and Ecklonia maxima [7,8,11]. An increase in leaf area and chlorophyll content are common plant responses to seaweed extract treatment. Cytokinins present in the seaweed extracts stimulate cell division, resulting in enlarged leaf area, and also stimulate chlorophyll biosynthesis, whereas betaines slow chlorophyll degradation and delay leaf senescence [7,8]. Ascophyllum nodosum extracts applied on foliage or to soil caused an increase in the leaf chlorophyll content of French bean, tomato, barley, maize, wheat, pepper, and strawberry [8,11,12]. A one-year study carried out in Iraq showed an increase in chlorophyll content in potato following the application of brown seaweed Sargassum extracts [13]. Foliar application of seaweed extracts Ascophyllum nodosum and Ecklonia maxima increased potato yield [14-16]. Biostimulants based on seaweed extracts improved plant growth and yield of wheat, barley, maize, potato, tomato, pepper, onion, and carrot $[7,8,10,11]$.

The biological activity of humic substances depends on their source, chemical structure, and concentration. Humic substances may influence both respiration and photosynthesis. One of the effects of humic substances applied to growing plants was an increase in chlorophyll content, which can affect photosynthesis [17]. Leonardite is the most common commercial source of humic substances. Leonardite humic acids stimulate melon and soybean growth and chlorophyll synthesis [6]. A one-year study carried out in Iraq showed an increase in chlorophyll content in potato following the application of humic and fulvic acids in HumiMax [13]. A one-year study carried out in Egypt showed that the application of humic acid under water stress conditions enhanced the leaf chlorophyll content of very early potato cultivars [18]. Application of humic substances originating from leonardite increased potato yield and nutrient uptake [19]. In most experiments, foliar or soil application of humic and fulvic acids increased potato yield [13,20,21], but one study showed no clear effect of humic and fulvic acids on the potato yield [22]. Humic and fulvic acids improved plant growth and yield quality of wheat, maize, tomato, pepper and cucumber [2,22-24]. The effect of humic acids on plant growth depends of their source and concentration, and on the date and method (foliar or soil) of application, as well as the plant species and environmental conditions [9,17].

There is a relationship between leaf chlorophyll content and Soil Plant Analysis Development (SPAD) index [25]. Leaf SPAD values is related to nutrient plant status, especially nitrogen [26,27]. There was a relationship found between SPAD value and potato yield. A higher SPAD does not always guarantee a higher potato yield [28-31]. Plant-based biostimulants increased SPAD index and marketable yield of tomato and rocket [32-34].

To date, few studies have been focused on the effect of seaweed extract and humic acid application in early crop potato culture. The aim of the study was to determine the effect of foliar application of brown seaweed extracts and humic acids on the asssimilation area and chlorophyll content of very early potato cultivars. In the current study, it was hypothesised that seaweed extracts and humic acids could contribute to increasing assimilation area and chlorophyll content and, as a result, increase the early crop potato yield. The assumption was also made that the response to the application of these biostimulants depends on the cultivar and environmental conditions.

\section{Materials and Methods}

\subsection{Experimental Site and Season}

The study was carried out in central-eastern Poland $\left(52^{\circ} 03^{\prime} \mathrm{N}, 22^{\circ} 33^{\prime} \mathrm{E}\right)$, over three growing season 2012-2014, on Luvisol with a low total nitrogen content, a high content of available phosphorus, a medium-to-high content of potassium and a low-to-medium content of magnesium, with an acidic-to-slightly-acid reaction. Spring triticale was grown as a potato forecrop. Farmyard manure 
was applied in autumn, at rate of $25 \mathrm{t} \cdot \mathrm{ha}^{-1}$, and mineral fertilizers were applied at rates of $80 \mathrm{~kg} \mathrm{~N}$ (ammonium nitrate), $35 \mathrm{~kg} \mathrm{P}$ (superphosphate) and $100 \mathrm{~kg} \mathrm{~K}$ (potassium sulphate) per hectare in spring. Potato cultivation was carried out according to common agronomical practice.

The thermal and moisture conditions during the potato growth period were different (Table 1). The mean air temperatures were above or similar to the long-term average. In 2012, total precipitation was similar and, in 2013 and 2014, above the long-term average, although it was unevenly distributed during the potato growth period. The most favourable hydrothermal conditions for early crop potato culture were in the warm and moderately wet growing season of 2012. The next year, 2013 was warm and with heavy rainfall, whereas 2014 was cool with heavy rainfall after plant emergence and a drought in the period of tuber growth.

Table 1. Hydrothermal conditions during potato growing period.

\begin{tabular}{|c|c|c|c|c|c|c|c|c|c|c|c|}
\hline \multirow[b]{2}{*}{ Month } & \multicolumn{4}{|c|}{ Temperature $\left({ }^{\circ} \mathrm{C}\right)$} & \multicolumn{4}{|c|}{ Rainfall (mm) } & \multicolumn{3}{|c|}{ Hydrothermal Index } \\
\hline & 2012 & 2013 & 2014 & $\begin{array}{c}\text { Many } \\
\text { year }\end{array}$ & 2012 & 2013 & 2014 & $\begin{array}{c}\text { Many } \\
\text { year }\end{array}$ & 2012 & 2013 & 2014 \\
\hline April & 8.9 & 7.4 & 9.8 & 8.3 & 29.9 & 36.0 & 45.0 & 41.2 & 1.1 & 1.6 & 1.5 \\
\hline May & 14.6 & 15.3 & 13.5 & 12.2 & 53.4 & 105.9 & 92.7 & 53.0 & 1.2 & 2.2 & 2.2 \\
\hline June & 16.3 & 18.0 & 15.4 & 16.8 & 76.2 & 98.8 & 55.4 & 63.8 & 1.5 & 1.8 & 1.2 \\
\hline
\end{tabular}

Hydrothermal index value: up to 0.4 extremely dry; $0.41-0.7$ very dry; $0.71-1.0$ dry; $1.01-1.3$ rather dry; $1.31-1.6$ optimal; 1.61-2 rather humid; $2.01-2.5$ humid; $2.51-3$ very humid; $>3$ extremely humid [35].

\subsection{Plant Material and Experimental Design}

The field experiment was established in a split-plot design with three replications. The experimental factors were: (1) plant biostimulant; and (2) cultivar. The potato plants were treated with three biostimulants: Bio-algeen S90 and Keplak SL containing seaweed extracts, and HumiPlant based on humic and fulvic acids. Bio-algeen S90 is an extract from Ascophyllum nodosum which contains amino acids, vitamins, alginic acids and other active components of seaweeds, as well as macronutrients $(\mathrm{N}$, $\mathrm{P}, \mathrm{K}, \mathrm{Ca}, \mathrm{Mg}$ ) and micronutrients (B, Fe, Cu, Mn, $\mathrm{Zn}, \mathrm{Se}, \mathrm{Co})$. Kelpak SL is an extract from Ecklonia maxima containing auxin $\left(11 \mathrm{mg} \cdot \mathrm{dm}^{-3}\right)$ and cytokinin $\left(0.031 \mathrm{mg} \cdot \mathrm{dm}^{-3}\right)$. HumiPlant is an extract from leonardite which contains humic acid $(12 \%)$ and fulvic acid $(6 \%)$ as well as macronutrients $(\mathrm{K}, \mathrm{Ca}$, $\mathrm{Mg}, \mathrm{S}$ ) and micronutrients ( $\mathrm{Fe}, \mathrm{Mn}, \mathrm{B}, \mathrm{Mo}, \mathrm{Zn}, \mathrm{Cu})$. The biostimulants were applied according to the manufacturers' recommendations: Bio-algeen $\mathrm{S} 90-2 \mathrm{dm}^{3} \cdot \mathrm{ha}^{-1}$ at the beginning of leaf development stage (BBCH 10-11) and $2 \mathrm{dm}^{3} \cdot \mathrm{ha}^{-1}$ two weeks after the first treatment, Kelpak SL-2 $\mathrm{dm}^{3} \cdot \mathrm{ha}^{-1}$ at the leaf development stage (BBCH 14-16) and $2 \mathrm{dm}^{3} \cdot \mathrm{ha}^{-1}$ two weeks after the first treatment, HumiPlant-2 $\mathrm{dm}^{3} \cdot \mathrm{ha}^{-1}$ at the leaf development stage (BBCH 14-16) and $2 \mathrm{dm}^{3} \cdot \mathrm{ha}^{-1}$ one week after the first treatment. Potato plants sprayed with water were used as a control without a biostimulant.

The most popular very early potato cultivars (Denar, Lord and Miłek) in the research area were grown. In successive years, 6-weeks pre-sprouted seed potatoes were planted on April 12, April 18 and April 7 with a row spacing of $0.25 \mathrm{~m}$ and $0.675 \mathrm{~m}$ between rows. The plots were six rows wide and $4 \mathrm{~m}$ long (96 plants per plot). Potatoes were harvested 75 days after planting (the end of June).

\subsection{Determination of Assimilation Area, Chlorophyll Content and Tuber Yield}

At the tuber formation stage (BBCH 41-43), the assimilation area, leaf area index (LAI), specific leaf area (SLA), and chlorophyll content (SPAD value) were determined. The measurements were made on four successive randomized plants per plot. The assimilation area was measured by the weight method [36]. SLA was calculated as the ratio of assimilation area/weight of leaves [37].

The chlorophyll content was estimated with non-destructive methods using a portable SPAD-502 chlorophyll meter (Minolta, Osaka, Japan). The measurements were made on the youngest fully expanded leaf, i.e., the fourth or fifth leaf from the top. 
The total and marketable tuber yield were determined. The marketable tuber yield constituted tubers with a transverse diameter above $30 \mathrm{~mm}$, excluding cracked and deformed tubers. The marketable tuber yield was determined on the basis of the total tuber yield of ten successive plants per plot using a hand calibrator with a square hole.

\subsection{Statistical Analysis}

The results of the study were analysed statistically with an analysis of variance (ANOVA) for the split-pot design. The significance of differences between the compared averages was verified using Tukey's test at the significance level $p \leq 0.05$.

\section{Results}

\subsection{Assimilation Area}

The effect of biostimulants on the assimilation area depended on the weather conditions during potato growth (Table 2). In the year with the highest air temperature and heavy rainfall after plant emergence (2013), the greatest enlargement of the assimilation area was caused by Kelpak SL, whereas in the year with the lowest air temperature and heavy rainfall after plant emergence (2014), the greatest enlargement of assimilation area was caused by Bio-algeen S90. The assimilation areas were larger, on average, by $0.0624 \mathrm{~m}^{2}(11.5 \%)$ and $0.0941 \mathrm{~m}^{2}(10 \%)$ respectively, and the leaf area index (LAI) was higher by 0.37 and 0.56 compared with the plants from the control group without a biostimulant. Regardless of the biostimulant applied, the assimilation area was largest in the year with the highest air temperature and moderate rainfall at the end of May (Table 3).

Table 2. Assimilation area in relation to plant biostimulant, potato growing season and cultivar.

\begin{tabular}{|c|c|c|c|c|c|c|}
\hline \multirow{2}{*}{ Plant Biostimulant } & \multicolumn{3}{|c|}{ Years } & \multicolumn{3}{|c|}{ Cultivar } \\
\hline & 2012 & 2013 & 2014 & Denar & Lord & Miłek \\
\hline \multicolumn{7}{|c|}{ Assimilation leaf area $\left(\mathrm{m}^{2}\right)$} \\
\hline Without biostimulant & $0.7131 \mathrm{~b}$ & $0.5411 \mathrm{~b}$ & $0.9438 \mathrm{~b}$ & $0.7214 \mathrm{a}$ & $0.6425 \mathrm{~b}$ & $0.8341 \mathrm{a}$ \\
\hline Bio-algeen S90 & $0.7847 \mathrm{a}$ & $0.5746 \mathrm{ab}$ & $1.0379 \mathrm{a}$ & $0.8120 \mathrm{a}$ & $0.8008 \mathrm{a}$ & $0.7845 \mathrm{a}$ \\
\hline Kelpak SL & $0.7964 \mathrm{a}$ & $0.6035 \mathrm{a}$ & $0.9434 \mathrm{~b}$ & $0.7871 \mathrm{a}$ & $0.7636 \mathrm{ab}$ & $0.7926 \mathrm{a}$ \\
\hline HumiPlant & $0.7963 \mathrm{a}$ & $0.5947 \mathrm{ab}$ & $0.9170 \mathrm{~b}$ & $0.7592 \mathrm{a}$ & $0.6903 \mathrm{~b}$ & $0.8584 \mathrm{a}$ \\
\hline \multicolumn{7}{|c|}{$\mathrm{LAI}\left(\mathrm{m}^{2} \cdot \mathrm{m}^{-1}\right)$} \\
\hline Without biostimulant & $4.22 \mathrm{~b}$ & $3.21 \mathrm{~b}$ & $5.59 \mathrm{~b}$ & $4.27 \mathrm{a}$ & $3.81 \mathrm{~b}$ & $4.49 \mathrm{a}$ \\
\hline Bio-algeen S90 & $4.65 \mathrm{a}$ & $3.41 \mathrm{ab}$ & $6.15 \mathrm{a}$ & $4.81 \mathrm{a}$ & $4.75 \mathrm{a}$ & $4.65 \mathrm{a}$ \\
\hline Kelpak SL & $4.72 \mathrm{a}$ & $3.58 \mathrm{a}$ & $5.59 \mathrm{~b}$ & $4.66 \mathrm{a}$ & $4.43 \mathrm{ab}$ & $4.70 \mathrm{a}$ \\
\hline HumiPlant & $4.72 \mathrm{a}$ & $3.52 \mathrm{ab}$ & $5.43 \mathrm{~b}$ & $4.46 \mathrm{a}$ & $4.09 \mathrm{~b}$ & $5.09 \mathrm{a}$ \\
\hline \multicolumn{7}{|c|}{$\operatorname{SLA}\left(\mathrm{m}^{2} \cdot \mathrm{kg}^{-1}\right)$} \\
\hline Without biostimulant & $2.87 \mathrm{~b}$ & $3.63 \mathrm{a}$ & $3.33 \mathrm{a}$ & $3.37 \mathrm{a}$ & $3.26 \mathrm{a}$ & $3.20 \mathrm{a}$ \\
\hline Bio-algeen S90 & $3.20 \mathrm{a}$ & $3.53 \mathrm{a}$ & $3.41 \mathrm{a}$ & $3.38 \mathrm{a}$ & $3.36 \mathrm{a}$ & $3.41 \mathrm{a}$ \\
\hline Kelpak SL & $3.07 \mathrm{ab}$ & $3.65 \mathrm{a}$ & $3.32 \mathrm{a}$ & $3.37 \mathrm{a}$ & $3.33 \mathrm{a}$ & $3.34 \mathrm{a}$ \\
\hline HumiPlant & $3.12 \mathrm{a}$ & $3.54 \mathrm{a}$ & $3.32 \mathrm{a}$ & $3.21 \mathrm{a}$ & $3.31 \mathrm{a}$ & $3.46 \mathrm{a}$ \\
\hline
\end{tabular}

Means within columns followed by the same letters do not differ significantly at $p \leq 0.05$.

The potato cultivars tested showed different responses to the biostimulants applied (Table 2). The type of biostimulant had a greatest effect on the assimilation area of the 'Lord' cultivar. The greatest enlargement of the assimilation area of 'Lord' was caused by Bio-algen S90. Following the application of this biostimulant, the assimilation area of 'Lord' was larger, on average, by $0.1583 \mathrm{~m}^{2}(24.5 \%)$ and the LAI value was higher by 0.94 compared with the plants from the control without biostimulant. The differences were highest in the year with a low air temperature and heavy rainfall after the plant emergence (2014). Despite the biostimulant applied, the assimilation area was higher for 'Miłek' than for 'Denar' and 'Lord' (Table 3). 
Table 3. Assimilation area in relation to potato growing season and cultivar.

\begin{tabular}{|c|c|c|c|c|}
\hline Year and Cultivar & $\begin{array}{c}\text { Weight of Leaves } \\
\text { (kg) }\end{array}$ & $\begin{array}{c}\text { Assimilation Leaf } \\
\text { Area }\left(\mathrm{m}^{2}\right)\end{array}$ & $\operatorname{LAI}\left(\mathrm{m}^{2} \cdot \mathrm{m}^{-1}\right)$ & $\operatorname{SLA}\left(\mathrm{m}^{2} \cdot \mathrm{kg}^{-1}\right)$ \\
\hline \multicolumn{5}{|c|}{ Year } \\
\hline 2012 & $0.254 \mathrm{~b}$ & $0.7726 \mathrm{~b}$ & $4.58 \mathrm{~b}$ & $3.06 \mathrm{c}$ \\
\hline 2013 & $0.169 \mathrm{c}$ & $0.5785 \mathrm{c}$ & $3.43 c$ & $3.59 \mathrm{a}$ \\
\hline 2014 & $0.287 \mathrm{a}$ & $0.9605 a$ & $5.69 \mathrm{a}$ & $3.35 \mathrm{~b}$ \\
\hline \multicolumn{5}{|c|}{ Cultivar } \\
\hline Denar & $0.235 \mathrm{ab}$ & $0.7699 \mathrm{~b}$ & $4.56 \mathrm{~b}$ & $3.33 \mathrm{a}$ \\
\hline Lord & $0.222 \mathrm{~b}$ & $0.7243 \mathrm{c}$ & $4.29 c$ & $3.31 \mathrm{a}$ \\
\hline Miłek & $0.251 \mathrm{a}$ & $0.8174 \mathrm{a}$ & $4.84 \mathrm{a}$ & $3.35 \mathrm{a}$ \\
\hline
\end{tabular}

Means within columns followed by the same letters do not differ significantly at $p \leq 0.05$.

Only in a warm and moderately wet growing season (2012), following application of Bio-algeen S90 and HumiPlant, was the specific leaf area (SLA) higher, on average, by $0.29 \mathrm{~m}^{2} \cdot \mathrm{kg}^{-1}$ compared with the plants from the control group without biostimulant (Table 2). With the use of Kelpak SL, the difference was smaller and not statistically confirmed. The SLA depended to a greater extent on the weather conditions during potato growth. Irrespective of the treatment (with or without biostimulant), the SLA was highest in the year with the highest air temperature and heavy rainfall after plant emergence (Table 3). The type of biostimulant and cultivar interaction effect on SLA was not statistically confirmed (Table 2). Regardless of the treatment, the SLA values of the potato tested cultivars were similar (Table 3).

\subsection{Chlorophyll Content (SPAD Value)}

The biostimulants used in the experiment had no significant effect on the chlorophyll content in leaves (Figure 1). The SPAD value depended to a greater extent on the cultivar and weather or soil conditions during potato growth. Irrespective of the treatment (with or without biostimulant), the SPAD values were higher for 'Denar' and 'Lord' than 'Miłek'. The SPAD was highest in the warm and wet growing season (2013) and, at the same time, the highest content of total nitrogen and available magnesium in soil (Figure 2).

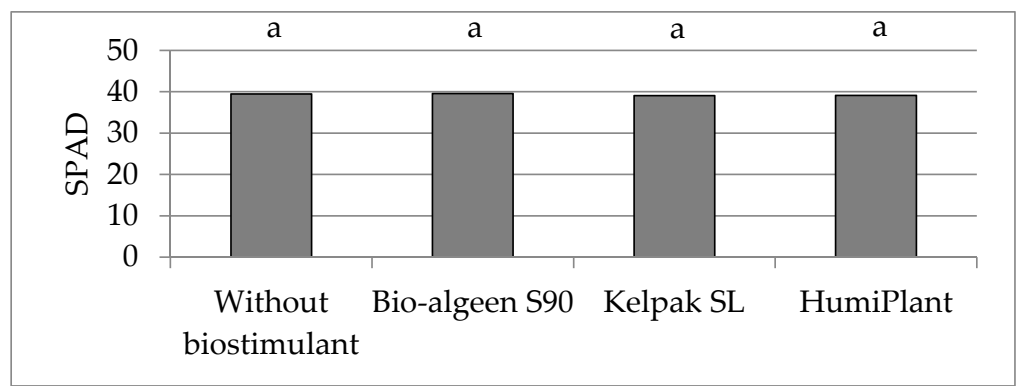

Figure 1. Effect of plant biostimulants on chlorophyll content (Soil Plant Analysis Development (SPAD) value); average of the three year tests on three cultivars. Means followed by the same letters do not differ significantly at $p \leq 0.05$. 

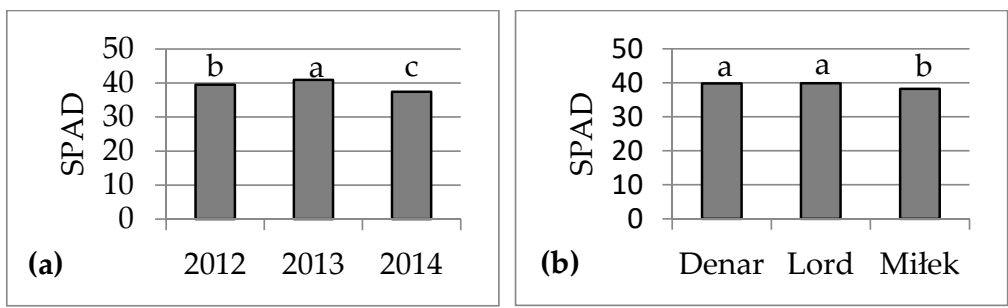

Figure 2. Chlorophyll content (SPAD value) in relation to potato growing season (a) and cultivar (b).

Means followed by the same letters do not differ significantly at $p \leq 0.05$.

\subsection{Relationship between Tuber Yield, Assimilation Area and Chlorophyll Content (SPAD Value)}

The biostimulants used in the experiment had no effect on the weight of leaves [38], but caused enlargement of the assimilation area (Table 4). Over the three years of the study, the assimilation area was larger, on average, by $0.0505 \mathrm{~m}^{2}(7 \%)$ and the LAI was higher by 0.30 compared with the plants from the control group without a biostimulant. The biostimulants had no significant effect on the SLA and SPAD (Figure 1).

Table 4. Effect of plant biostimulants on assimilation area; average of the three year tests on three cultivars.

\begin{tabular}{ccccc}
\hline Plant biostimulant & $\begin{array}{c}\text { Weight of Leaves } \\
\mathbf{( k g})\end{array}$ & $\begin{array}{c}\text { Assimilation Leaf } \\
\text { Area }\left(\mathbf{m}^{\mathbf{2}}\right)\end{array}$ & LAI $\left(\mathbf{m}^{\mathbf{2}} \cdot \mathbf{m}^{-\mathbf{1}}\right)$ & SLA $\left(\mathbf{m}^{\mathbf{2}} \cdot \mathbf{k g}^{-\mathbf{1}}\right)$ \\
\hline Without & $0.234 \mathrm{a}$ & $0.7327 \mathrm{~b}$ & $4.34 \mathrm{~b}$ & $3.28 \mathrm{a}$ \\
biostimulant & $0.243 \mathrm{a}$ & $0.7991 \mathrm{a}$ & $4.74 \mathrm{a}$ & $3.38 \mathrm{a}$ \\
Bio-algeen S90 & $0.268 \mathrm{a}$ & $0.7811 \mathrm{a}$ & $4.63 \mathrm{a}$ & $3.345 \mathrm{a}$ \\
Kelpak SL & $0.230 \mathrm{a}$ & $0.7693 \mathrm{a}$ & $4.56 \mathrm{a}$ & $3.33 \mathrm{a}$ \\
HumiPLant & 0
\end{tabular}

Means within columns followed by the same letters do not differ significantly at $p \leq 0.05$.

The biostimulants used in the experiment had a significant effect on the tuber yield [38]. The yield-increasing effects of biostimulants were comparable (Table 5). In the three years of the study, the total tuber yield was higher, on average, by $2.64 \mathrm{t}^{-\mathrm{ha}^{-1}}(7.7 \%)$ and marketable tuber yield (diameter above $30 \mathrm{~mm}$ ) by $2.15 \mathrm{t} \cdot \mathrm{ha}^{-1}(6.5 \%)$. The yield-increasing effect of biostimulants depended on weather conditions during the potato growing season. Bio-algeen S90 and Kelpak SL caused the highest increase in tuber yield in the warm and very wet growing season (2013), and HumiPlant in the year with a low air temperature and a drought in the period of tuber growth (2014).

The tuber yield was not significantly correlated with the weight and assimilation leaf area or LAI (Table 6). A significant negative correlation was found between the marketable tuber yield and SLA. No significant correlation was found between the marketable tuber yield and SPAD value. 
Table 5. Tuber yield in relation to plant biostimulant, potato growing season and cultivar.

\begin{tabular}{cccccccc}
\hline \multirow{2}{*}{ Plant Biostimulant } & \multicolumn{9}{c}{ Years } & Cultivar & \multirow{2}{*}{ Mean } \\
\cline { 2 - 6 } & $\mathbf{2 0 1 2}$ & $\mathbf{2 0 1 3}$ & $\mathbf{2 0 1 4}$ & Denar & Lord & Miłek & \\
\hline Without biostimulant & $40.26 \mathrm{a}$ & $31.46 \mathrm{~b}$ & $31.38 \mathrm{~b}$ & $33.54 \mathrm{a}$ & $34.49 \mathrm{a}$ & $35.07 \mathrm{a}$ & $34.37 \mathrm{~b}$ \\
\hline Bio-algeen S90 & $40.45 \mathrm{a}$ & $36.88 \mathrm{a}$ & $33.19 \mathrm{ab}$ & $36.97 \mathrm{a}$ & $37.66 \mathrm{a}$ & $35.89 \mathrm{a}$ & $36.84 \mathrm{a}$ \\
\hline Kelpak SL & $41.43 \mathrm{a}$ & $36.30 \mathrm{a}$ & $33.40 \mathrm{ab}$ & $35.63 \mathrm{a}$ & $37.64 \mathrm{a}$ & $37.89 \mathrm{a}$ & $37.04 \mathrm{a}$ \\
\hline HumiPlant & $42.29 \mathrm{a}$ & $33.85 \mathrm{~b}$ & $35.27 \mathrm{a}$ & $36.76 \mathrm{a}$ & $37.99 \mathrm{a}$ & $36.66 \mathrm{a}$ & $37.14 \mathrm{a}$ \\
\hline \multicolumn{7}{c}{ Marketable tuber yield $\left(\mathrm{t} \cdot \mathrm{ha}^{-1}\right)$} \\
\hline Without biostimulant & $39.49 \mathrm{a}$ & $29.75 \mathrm{~b}$ & $29.34 \mathrm{~b}$ & $31.84 \mathrm{a}$ & $33.10 \mathrm{a}$ & $33.64 \mathrm{a}$ & $32.86 \mathrm{~b}$ \\
\hline Bio-algeen S90 & $38.96 \mathrm{a}$ & $34.64 \mathrm{a}$ & $30.62 \mathrm{~b}$ & $34.49 \mathrm{a}$ & $35.47 \mathrm{a}$ & $34.26 \mathrm{a}$ & $34.74 \mathrm{ab}$ \\
\hline Kelpak SL & $40.22 \mathrm{a}$ & $34.12 \mathrm{a}$ & $30.62 \mathrm{~b}$ & $33.50 \mathrm{a}$ & $35.46 \mathrm{a}$ & $36.00 \mathrm{a}$ & $34.99 \mathrm{a}$ \\
\hline HumiPlant & $41.43 \mathrm{a}$ & $31.61 \mathrm{ab}$ & $32.83 \mathrm{a}$ & $34.95 \mathrm{a}$ & $36.21 \mathrm{a}$ & $34.71 \mathrm{a}$ & $35.29 \mathrm{a}$ \\
\hline
\end{tabular}

Means within columns followed by the same letters do not differ significantly at $p \leq 0.05$.

Table 6. Correlation coefficient between tuber yield and assimilation area and SPAD.

\begin{tabular}{ccc}
\hline Plant Growth Characteristics & Total Tuber Yield & Marketable Tuber Yield \\
\hline Weight of leaves & +0.1496 & +0.1356 \\
Assimilation leaf area & -0.0199 & -0.0488 \\
LAI & -0.0206 & -0.0494 \\
SLA & $-0.5537^{*}$ & $-0.5767^{*}$ \\
SPAD & +0.1886 & +0.1894 \\
\hline
\end{tabular}

* significant at $p \leq 0.05$.

\subsection{Effect of Experimental Factors on Assimilation Area, Chlorophyll Content and Tuber Yield}

The effect of the experimental factors and their interactions on potato assimilation area and chlorophyll content (SPAD value) are presented in Table 7.

Table 7. Effect of experimental factors on assimilation area, chlorophyll content (SPAD value) and tuber yield.

\begin{tabular}{|c|c|c|c|c|c|c|c|}
\hline $\begin{array}{c}\text { Experimental } \\
\text { Factors }\end{array}$ & $\begin{array}{l}\text { Weight of } \\
\text { Leaves }\end{array}$ & $\begin{array}{c}\text { Assimilation } \\
\text { Leaf Area }\end{array}$ & LAI & SLA & SPAD & $\begin{array}{c}\text { Total Tuber } \\
\text { Yield }\end{array}$ & $\begin{array}{l}\text { Marketable } \\
\text { Tuber Yield }\end{array}$ \\
\hline Year $(\mathrm{Y})$ & $* *$ & $* *$ & $* *$ & $* *$ & $* *$ & ** & $* *$ \\
\hline Biostimulant (B) & ns & $* *$ & $* *$ & ns & ns & * & * \\
\hline $\mathrm{Y} \times \mathrm{B}$ & ns & $* *$ & $* *$ & $*$ & ns & * & * \\
\hline Cultivar (C) & * & $* *$ & $* *$ & ns & $* *$ & ns & ns \\
\hline $\mathrm{Y} \times \mathrm{C}$ & ns & $* *$ & $* *$ & ns & ns & $* *$ & $* *$ \\
\hline $\mathrm{B} \times \mathrm{C}$ & * & $* *$ & $* *$ & ns & ns & ns & ns \\
\hline $\mathrm{Y} \times \mathrm{B} \times \mathrm{C}$ & ns & * & * & $* *$ & ns & ns & ns \\
\hline
\end{tabular}

${ }^{*}$ significant at $p \leq 0.05,{ }^{* *}$ significant at $p \leq 0.01$, ns-non-significant.

\section{Discussion}

In sustainable crop production, biostimulants play an important role in improving plant growth and crop quality. Assimilation area and chlorophyll content are important parameters of assessment plant growth. The biostimulants used in the experiment caused enlargement of assimilation area, but had no effect on the chlorophyll content (SPAD value) in leaves of very early potato cultivars. SPAD value depended on the cultivar and weather or soil conditions to a greater extent. The effect of 
foliar application of seaweed extracts on potato assimilation area was comparable to humic and fulvic acids. In the three years of the study, following biostimulant application, the average leaf area index (LAI) was 4.64, being higher by 0.30 compared to the average for the untreated control group. Potato cultivars showed different responses to the applied biostimulants. Studies have shown the highest light absorption efficiency values at the LAI value of 3 , which corresponded to maximum ground cover. If potato LAI exceeds 3 , the intercepted photosynthetically active radiation value changes very little $[39,40]$. According to Howlader and Hoque [41], irrespective of potato cultivars, LAI increased progressively over time, reaching a peak at 60 days after planting and thereafter declining. The rate of assimilation area expansion showed the interaction between genotype and environment and varied by year [42], which was confirmed in the present study. The effect of seaweed extracts on potato assimilation area depended on the weather conditions after plant emergence. In the year with the highest air temperature and heavy rainfall after plant emergence, the assimilation area was larger after the application of Kelpak SL (Ecklonia maxima), whereas in the year with the lowest air temperature and with heavy rainfall after plant emergence, the assimilation area was larger after the application of Bio-algeen S90 (Ascophyllum nodosum). Potato plants are very sensitive to heat stress. In general, heat stress increases plant height, reduces leaf size, increases leaf chlorophyll content, and severely reduces tuber mass [43]. Kelpak SL contains auxins and cytokinins in a ratio of 350/1. Exogenous auxin plays an important role in plant stress resistance. The action of auxin depends on its concentration, the light conditions and carbohydrate content in the plant [44]. Exogenous cytokinins also play an important role in plant adaptation to environmental stresses [45]. Cytokinins present in the seaweed extracts stimulate cell division, resulting in enlarged leaf area $[7,8]$, which was confirmed in the present study.

The leaf area index describes the growth of lowland fields, whereas the growth of individual plants is characterized by the specific leaf area (SLA). Biostimulants caused enlargement of the assimilation area, but had no effect on the SLA. The SLA for potato depends on the cultivar and growth stage, and temperature [42], which was confirmed in the present study. Early foliar expansion of potato is associated with a strong increase in SLA [41].

Foliar or soil application of Ascophyllum nodosum extracts caused an increase in the chlorophyll content of some agriculture (barley, wheat, maize) and horticulture (French bean, tomato, pepper, strawberry) plants $[8,11,12]$, which was not confirmed in the present study. A study carried out in Egypt showed that the application of humic acid under water stress conditions enhanced the chlorophyll content of very early potato 'Spunta' grown on sandy soil [18], which was not confirmed in the present study with very early potato cultivars grown on loamy soil (Luvisol). A one-year study carried out in Iraq showed that foliar application of humic and fulvic acids caused an increase in the chlorophyll content of medium-early potato cultivar [13]. The effect of humic acids depends on their source and concentration, and on the date and method of application, as well as the plant species and cultivar [9]. The increase in chlorophyll alone does not necessarily result in higher yields $[17,26]$.

The biostimulants used in the experiment enhanced tolerance to abiotic stress and improved crop quality. In the three years of the study, the marketable tuber yield (diameter above $30 \mathrm{~mm}$ ) was higher, on average, by $2.15 \mathrm{t} \cdot \mathrm{ha}^{-1}$. Bio-algeen S90 and Keplak SL containing seaweed extracts produced better results in a warm and very wet growing season, whereas HumiPlant based on humic and fulvic acids produced better results in a year with lower air temperature and with drought periods during potato growth.

A correlation between the tuber yield and assimilation area was not found. Li et al. [46] found a significant positive correlation between LAI and tuber yield, which suggests that the enlargement of leaf area could enhance the export of photosynthetic products and cause an increase in tuber yield. According to Ascione et al. [47], the tuber growth rate is only slightly correlated with LAI, and still less so with SLA, which was not confirmed in the present study. A significant negative correlation was found between the total and marketable (diameter above $30 \mathrm{~mm}$ ) tuber yield and SLA.

No correlation was found between the tuber yield of three very early potato cultivars and SPAD value measured on the fourth or fifth leaf from the top at the tuber formation stage (BBCH 41-43), 
which suggest that the biostimulants used in the experiment had no effect on the plant nitrogen status. Bărăscu et al. [30] found a significant negative correlation between SPAD measured on the fourth and fifth leaves from the top and the tuber weight of two mid-early potato cultivars, which could have been associated with oxidative stress [29]. SPAD index as an indicator of crop nitrogen status may be used for the prediction of the potato yield, however a higher SPAD does not always guarantee a higher tuber yield $[26,28,31]$. SPAD value is a useful indicator for selecting the high yield cultivars in the early period, however, no single threshold leaf SPAD value can be used for all potato cultivars. The SPAD value can predict the level of tuber yield if the value is calibrated for a particular potato cultivar $[28,31]$. Establishing threshold SPAD value is quite difficult due to the influence of climate and technical factors. SPAD values can be affected by leaf age and position, as well as, time of the day $[26,27]$. As a rule SPAD measurements are carried out on the third-fifth leaf from the top. Recently it was demonstrated that there is a significance difference in SPAD values between the upper and lower leaves among potato cultivars. It was shown that cultivar affects the SPAD values of the fourth and eighth leaf, but does not affect SPAD value of the fourth-eighth leaves and the difference between SPAD of the fourth and eighth leaf. Therefore the SPAD values of the fourth-eighth leaves could be applied as a general index of nitrogen status across different potato cultivars [27].

\section{Conclusions}

In conclusion, the foliar application of seaweed extracts Ascophyllum nodosum (Bio-algeen S90) and Ecklonia maxima (Kelpak SL), as well as humic and fulvic acids from leonardite (HumiPlant), resulted in enlargement of the assimilation area of very early potato cultivars, but had no effect on the SLA or chlorophyll content (SPAD value). The assimilation area was larger, on average, by $0.0505 \mathrm{~m}^{2}(7 \%)$, and LAI was higher by 0.30 compared with the plants from the control group without a biostimulant. The SLA and SPAD depend on the cultivar and weather conditions, or nitrogen and magnesium content, in soil to a greater extent. These biostimulants enhanced abiotic stress tolerance and increased marketable tuber yield (diameter above $30 \mathrm{~mm}$ ) 75 days after planting (the end of June), on average, by $2.15 \mathrm{t} \cdot \mathrm{ha}^{-1}$. Bio-algeen S90 and Keplak SL containing seaweed extracts produced better results in a warm and very wet growing season, whereas HumiPlant based on humic and fulvic acids produced better results in a year with lower air temperature and with drought periods during potato growth. No correlation was found between the tuber yield and assimilation area or between the tuber yield and SPAD value, although a significant negative correlation was found between the tuber yield and SLA.

Author Contributions: Conceptualization, W.W. and T.D.; methodology and formal analysis, W.W.; investigation, W.W. and T.D.; writing —original draft preparation, W.W. and T.D.; writing-review and editing, W.W. All authors have read and agreed to the published version of the manuscript.

Funding: This research was financed from the science grant granted by the Polish Ministry of Science and Higher Education, research theme number 218/05/S.

Conflicts of Interest: The authors declare no conflict of interest.

\section{References}

1. Carrão, H.; Naumann, G.; Barbosa, P. Mapping global patterns of drought risk: An empirical framework based on sub-national estimates of hazard, exposure and vulnerability. Glob. Environ. Chang. 2016, 39, 108-124. [CrossRef]

2. Calvo, P.; Nelson, L.; Kloepper, J.W. Agricultural uses of plant biostimulans. Plant Soil 2014, 383, 3-41. [CrossRef]

3. du Jardin, P. Plant biostimulants: Definition, concept. main categories and regulation. Sci. Hort. 2015, 196, 3-14. [CrossRef]

4. Van Oosten, M.J.; Pepe, O.; De Pascale, S.; Silletti, S.; Maggio, A. The role of biostimulants and bioeffectors as alleviators of abiotic stress in crop plants. Chem. Biol. Technol. Agric. 2017, 4, 1-12. [CrossRef]

5. Bulgari, R.; Franzoni, G.; Ferrante, A. Biostimulants application in horticultural crops under abiotic stress conditions. Agronomy 2019, 9, 306. [CrossRef] 
6. Chen, Y.; Clapp, C.E.; Magen, H. Mechanism of plant growth stimulation by humic substances: The role of organo-iron complex. Soil Sci. Plant Nutr. 2004, 50, 1089-1095. [CrossRef]

7. Khan, W.; Rayirath, U.P.; Subramanian, S.; Jithesh, M.N.; Rayorath, P.; Hodges, D.M.; Critchley, A.T.; Craige, J.S.; Norrie, J.; Prithiviraj, B. Seaweed extracts as biostimulants of plant growth and development. J. Plant Growth Regul. 2009, 28, 386-399. [CrossRef]

8. Sharma, H.S.S.; Fleming, C.; Selby, C.; Rao, J.R.; Martin, T. Plant biostimulants: A review on the processing of macroalgae and use of extracts for crop management to reduce abiotic and biotic stresses. J. Appl. Phycol. 2014, 26, 465-490. [CrossRef]

9. Canellas, L.P.; Olivares, F.L.; Aguiar, N.O.; Jones, D.L.; Nebbioso, N.; Mazzei, P.; Piccolo, A. Humic and fulvic acids as biostimulants in horticulture. Sci. Hort. 2015, 196, 15-27. [CrossRef]

10. Begum, M.; Bordoloi, B.C.; Singha, D.D.; Ojha, N.J. Role of seaweed extract on growth, yield and quality of some agricultural crops: A review. Agric. Rev. 2018, 39, 321-326. [CrossRef]

11. Battacharyya, D.; Babgohari, M.Z.; Rathor, P.; Prithiviraj, B. Seaweed extracts as biostimulants in horticulture. Sci. Hort. 2015, 196, 39-48. [CrossRef]

12. Shukla, P.S.; Manti, E.G.; Adil, M.; Bajpai, S.; Critchley, A.T.; Prithiviraj, B. Ascophyllum nodosum-Based biostimulants: Sustainable applications in agriculture for the stimulation of plant growth, stress tolerance, and disease management. Front. Plant Sci. 2019, 10, 655. [CrossRef] [PubMed]

13. Sarhan, T.Z. Effect of humic acid and seaweed extracts on growth and yield of potato plant (Solanum tuberosum L.) Desiree cv. Mesop. J. Agric. 2011, 39, 19-25. [CrossRef]

14. Yanbo, X. Effect of bio-stimulant Kelpak on potato yield. Chin. Potato J. 2008, 22, 134-136.

15. Haider, M.W.; Ayyub, C.M.; Pervez, M.A.; Asad, H.U.; Manan, A.; Raza, S.A.; Ashraf, I. Impact of foliar application of seaweed extract on growth, yield and quality of potato (Solanum tuberosum L.). Soil Environ. 2012, 31, 157-162.

16. Wierzbowska, J.; Cwalina-Ambroziak, B.; Głosek-Sobieraj, M.; Sienkiewicz, S. Effect of biostimulators on yield and selected chemical properties of potato. J. Elem. 2015, 20, 575-768. [CrossRef]

17. Nardi, S.; Pizzeghello, D.; Muscolo, A.; Vianello, A. Physiological effects of humic substances on higher plants. Soil Biol. Biochem. 2002, 34, 1527-1536. [CrossRef]

18. Selim, E.M.; Shedeed, S.I.; Asaad, F.F.; El-Neklawy, A.S. Interactive effect of humic acid and water stress on chlorophyll and mineral nutrient contents of potato plants. J. App. Sci. Res. 2012, 8, 531-537.

19. Verlinden, G.; Pycke, J.; Mertens, J.; Debersaques, F.; Verheyen, K.; Baert, G.; Bries, J.; Haesaert, G. Application of humic substances results in consistent increase in crop yield and nutrient uptake. J. Plant Nutr. 2009, 32, 1407-1426. [CrossRef]

20. Alenazi, M.; Wahb-Allah, M.A.; Abdel-Razzak, H.S.; Ibrahim, A.A.; Alsadon, A. Water regimes and humic acid application influences potato growth, yield, tuber quality and water use efficiency. Am. J. Potato Res. 2016, 93, 463-473. [CrossRef]

21. Zhang, Y.; Zhou, Q.; Li, Y.; Xu, C.; He, S.; Huang, Y.; Yang, H.; Wang, M.; Liu, L.; Tang, M. Effect of fulvic acid on agronomic traits and yield of autumn potato. Agric. Sci. Technol. 2017, 18, 1448-1451.

22. Suh, H.Y.; Yoo, K.S.; Suh, S.G. Effect of foliar application of fulvic acid on plant growth and fruit quality of tomato (Lycoporsicon esculentum L.). Hort. Environ. Biotechnol. 2014, 55, 455-461. [CrossRef]

23. Karakurt, Y.; Unlu, H.; Unlu, H.; Padem, H. The influence of foliar and soli fertilization of humic acid on yield and quality of pepper. Acta Agric. Scand. B-PS 2009, 59, 233-237. [CrossRef]

24. Ozdamar Unlu, H.; Unlu, H.; Karakurt, Y.; Padem, H. Change in fruit yield and quality in response to foliar and soil humic acid application in cucumber. Sci. Res. Essays 2011, 6, 2800-2803.

25. Udding, J.; Gelang-Alfredsson, G.; Piikkki, K. Evaluating the relationship between leaf chlorophyll concentration and SPAD-502 chlorophyll meter readings. Photosynth. Res. 2007, 91, 37-46. [CrossRef]

26. Gianquinto, G.; Goffart, J.P.; Olivier, M.; Guarda, G.; Colauzzi, M.; Dalla Costa, L.; Delle Vedove, G.; Vos, J.; Mackerron, D.K.L. The use of hand-held chlorophyll meters as a tool to assess the nitrogen status and guide nitrogen fertilization of potato crop. Potato Res. 2004, 47, 35-80. [CrossRef]

27. Li, R.; Chen, J.; Qin, Y.; Fan, M. Possibility of using a SPAD chlorophyll meter to establish a normalized threshold index of nitrogen status in different potato cultivars. J. Plant Nutr. 2019, 42, 834-841. [CrossRef]

28. Su, Y.; Guo, H.; Chen, Y. Relationship between SPAD readings chlorophyll contents and yield of potato (Solanum tuberosum L.). Southwest China J. Agric. Sci. 2007, 4, 690-693. 
29. Raminez, D.A.; Yactayo, W.; Gutiérrez, R.; Mares, V.; De Mendiburu, F.; Posadas, A.; Quiroz, R. Chlorophyll concentration in leaves is an indicator of potato tuber yield in water-shortage conditions. Sci. Hort. 2014, 168, 202-209. [CrossRef]

30. Bărăscu, N.; Duda, M.M.; Olteanu, G. Study of dynamics SPAD and NDVI values of potato plants according to the differentiated fertilization. Bull. UASVM Agric. 2016, 73, 5-14. [CrossRef]

31. Dvořák, P.; Král, M. Effect of organic mulching on soil water potential and SPAD values as factors on yield of potatoes (Solanum tuberosum L.). Tarim Bilim. Derg. 2019, 25, 147-154. [CrossRef]

32. Caruso, G.; De Pascale, S.; Cozzolino, E.; Cuciniello, A.; Cenvinzo, V.; Bonini, P.; Colla, G.; Rouphael, Y. Yield and nutrition quality of vesuvian piennolo tomato PDO as affected by farming system and biostimulant application. Agronomy 2019, 9, 505. [CrossRef]

33. Dima, S.-O.; Neamtu, C.; Desliu-Avram, M.; Ghiurea, M.; Capra, L.; Radu, E.; Stoica, R.; Faraon, V.-A.; Zamfiropol-Cristea, V.; Constantinescu-Aruxandei, D.; et al. Plant biostimulant effects of baker's yeast vinasse and seleniu on tomatoes through foliar fertilization. Agronomy 2020, 10, 133. [CrossRef]

34. Di Mola, I.; Ottaiano, L.; Cozzolino, E.; Senatore, M.; Giordano, M.; El-Nakhel, C.; Sacco, A.; Rouphael, Y.; Colla, G.; Mori, M. Plant-based biostimulants influence the agronomical, physiological, and qualitative responses of baby rocket leaves under diverse nitrogen conditions. Plants 2019, 8, 522. [CrossRef] [PubMed]

35. Skowera, B. Changes of hydrothermal conditions in the Polish area (1971-2010). Fragm. Agron. 2014, 31, 74-87. (In Polish)

36. Wadas, W.; Kalinowski, K. Effect of titanium on assimilation leaf area and chlorophyll content of very early-maturing potato cultivars. Acta Sci. Pol. Agric. 2017, 16, 87-98.

37. Pietkiewicz, S. An indicator-based analysis of plant growth. Wiad. Bot. 1985, 29, 29-42. (In Polish)

38. Wadas, W.; Dziugiel, T. Growth and marketable potato (Solanum tuberosum L) tuber yield in response to foliar application of seaweed extract and humic acids. Appl. Ecol. Environ. Res. 2019, 6, 13219-13230.

39. de la Casa, A.; Ovando, G.; Bressanini, L.; Martinez, J.; Rodriguez, A. Radiation use efficiency in potato crop estimated from the foliage coverage. Agriscientia 2011, 28, 21-30. [CrossRef]

40. Camargo, D.C.; Montoya, F.; Moreno, M.A.; Ortega, J.F.; Córcoles, J.I. Impact of water deficit on light interception, radiation use efficiency and leaf area index in a potato crop (Solanum tuberosum L.). J. Agric. Sci. 2016, 154, 662-673. [CrossRef]

41. Howlader, O.; Hoque, M.A. Growth analysis and yield performance of four potato (Solanum tuberosum L.) varieties. Bangladesh J. Agric. Res. 2018, 43, 267-280. [CrossRef]

42. Van Delden, A.; Pecio, A.; Haverkort, A.J. Temperature response of early foliar expansion of potato and wheat. Ann. Bot. 2000, 86, 355-369. [CrossRef]

43. Tang, R.; Niu, S.; Zhang, G.; Chen, G.; Haroon, M.; Yang, Q.; Rajora, O.P.; Li, X.Q. Physiological and growth responses of potato cultivars to heat stress. Botany 2018, 96, 897-912. [CrossRef]

44. Kolachevskaya, O.O.; Lomin, S.N.; Arkhipov, D.V.; Romanov, G.A. Auxin in potato: Molecular aspects and emerging roles in tuber formation and stress resistance. Plant Cell Rep. 2019, 38, 681-698. [CrossRef] [PubMed]

45. Ha, S.; Vankova, R.; Yamaguchi-Shinozaki, K.; Shinozaki, K.; Tran, L.-S.P. Cytokinins: Metabolism and function in plant adaptation to environmental stresses. Trends Plant Sci. 2012, 17, 172-179. [CrossRef] [PubMed]

46. Li, J.; Zhong, Y.; Guo, H. Correlation of leaf area with yield and quality in potato. Chin. Potato J. 2013, 27, 34-37.

47. Ascione, S.; Ruggiero, C.; Vitale, C. Contribution of growth components on relative, plant, crop and tuber growth rate of nine potato cultivars in southern Italy. Int. J. Sci. 2013, 2, 1-11.

(C) 2020 by the authors. Licensee MDPI, Basel, Switzerland. This article is an open access article distributed under the terms and conditions of the Creative Commons Attribution (CC BY) license (http://creativecommons.org/licenses/by/4.0/). 